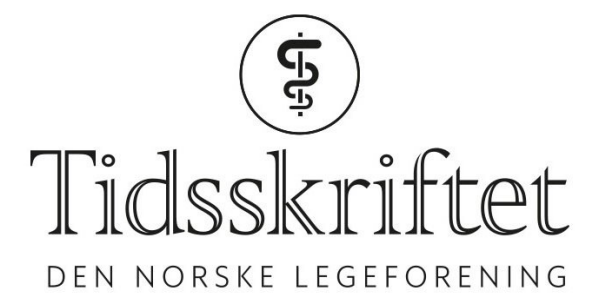

\title{
Hva får din indre klokke til å tikke?
}

LEDER

\section{MAJA ELSTAD}

E-post: maja.elstad@medisin.uio.no

Maja Elstad (f. 1976) er lege og arbeider som forsker ved Institutt for medisinske basalfag, Universitetet i Oslo. Hun forsker på samspillet mellom tidsavhengige oscillasjoner i blodstrøm, blodtrykk og temperaturregulering.

Forfatter har fylt ut ICMJE-skjemaet og oppgir ingen interessekonflikter.

\section{Biologiske klokker er temaet for årets nobelpris.}

Vi har alle følt det på kroppen. Sent uti nattevakten subber føttene over gulvet, man fryser, og timene frem til morgenmøtet virker uendelig lange. Alle har merket at kroppen har en døgnrytme, enten man jobber turnus eller krysser kontinenter.

Årets nobelpris i fysiologi eller medisin gikk til tre amerikanske professorer i medisin som har gitt oss forståelse av de molekylære nøkkelkomponentene av den indre klokken. Jeffrey C. Hall (University of Maine), Michael Rosbash (Brandeis University, Massachusetts) og Michael W. Young (Rockefeller University, New York) fikk prisen for oppdagelsen av mekanismene som styrer døgnrytmen (1). De tre har funnet ut hvordan den biologiske klokken virker hos planter, dyr og mennesker, og at alle celler har sin egen klokke.

Det startet med en bananfluemutant som hadde feil i sin indre klokke, og dermed visste forskerne hvor i DNA-et de kunne lete etter gener som styrte klokken. Hall og Rosbash klarte først å isolere et gen de kalte period i $1984(2,3)$. Hall og Rosbash satte inn genet period i mutanten, og bananfluen fikk tilbake en normal døgnrytme. Dette var et funksjonelt bevis på at genet period var direkte involvert i den indre klokken. Deretter viste de at proteinet PERIOD som period-genet kodet for, akkumulerer i cellekjernen om natten, og degraderes om dagen $(4,5)$. Proteinnivåene oscillerer synkront med døgnrytmen.

Etter denne oppdagelsen var det viktig å finne ut hvordan døgnrytmen etableres og opprettholdes. Hall og Rosbash hadde oppdaget at PERIOD akkumulerte i cellekjernen (6) og antok at proteinet fungerte som en tilbakereguleringsmekanisme på transkripsjonen av period-genet. Men hvordan kom PERIOD inn i cellekjernen? Tilbakereguleringsmekanismen var viktig å forstå. Her kommer Young inn i bildet med sine oppdagelser av genene timeless og doubletime. Oppdagelsen av den molekylære mekanismen av hvordan proteinproduksjonen reguleres var helt essensielt for å få til en syklus. Young oppdaget $\mathrm{i}$ 1994 et nytt klokkegen, timeless, som koder for proteinet TIMELESS (7). TIMELESS binder seg til PERIOD i cytosol før de to proteinene går sammen inn i cellekjernen og blokkerer genaktiviteten fra period.

Fortsatt gjensto spørsmålet hvordan frekvensen på oscillasjonen ble styrt. Young identifiserte genet, doubletime, som kodet for proteinet DOUBLETIME (8). Dette proteinet 
forsinker akkumuleringen av PERIOD, og slik tilpasses oscillasjonen døgnsyklusen.

Deretter identifiserte årets nobelprisvinnere flere proteiner, nødvendige for å aktivere period. Lys påvirker klokken ved å fjerne proteinet TIMELESS (9), dermed kan lys synkronisere klokken. Nobelprisvinnerne har altså beskrevet et selvregulerende urverk i cellene. Hos pattedyr og mennesker har genene og proteinene andre navn, men de indre klokkene fungerer etter de samme prinsippene. Til forskjell fra bananfluen som er gjennomsiktig og har lysfølsomme celleklokker, er det nucleus suprachiasmaticus, en kjerne i hypothalamus, som inneholder hovedklokken hos oss. Kjernen har direkte projeksjoner fra retina og er dermed lysfølsom. Den styrer søvn-våkenhets-syklusen, svingninger i kroppstemperatur og enkelte hormoner, som melatonin. I tillegg finnes det perifere klokker en rekke andre områder, i hjernen og i andre organer. Resetting av nucleus suprachiasmaticus er styrt av lys, mens de perifere klokkene styres av hormoner (10), spesielt, men kanskje ikke uventet, glukokortikoider.

Årets nobelprisvinnere i fysiologi eller medisin har åpnet vei for en rekke studier som kan få enorm betydning for hvordan vi innretter livene våre. De har spesielt rettet søkelyset mot nevropsykiatriske lidelser, der dysregulering av de perifere klokkene kan skje på molekylært nivå (11). Potensielt kan dette åpne for ny behandling av både søvnproblemer og alvorlige psykiatriske lidelser. En dårlig koordinert indre tidtaking kan bidra i utviklingen av mange av vår tids folkesykdommer, som overvekt, diabetes, høyt blodtrykk, kreft og depresjon (10).

\section{LITTERATUR:}

1. Nobelprize.org. The official web site of the Nobel Prize. https://www.nobelprize.org/(2.11.2017).

2. Zehring WA, Wheeler DA, Reddy P et al. P-element transformation with period locus DNA restores rhythmicity to mutant, arrhythmic Drosophila melanogaster. Cell 1984;39:369 - 76.

[PubMed][CrossRef]

3. Bargiello TA, Jackson FR, Young MW. Restoration of circadian behavioural rhythms by gene transfer in Drosophila. Nature 1984; 312: 752 - 4. [PubMed][CrossRef]

4. Siwicki KK, Eastman C, Petersen G et al. Antibodies to the period gene product of Drosophila reveal diverse tissue distribution and rhythmic changes in the visual system. Neuron 1988; 1: 141 - 50.

[PubMed][CrossRef]

5. Hardin PE, Hall JC, Rosbash M. Feedback of the Drosophila period gene product on circadian cycling of its messenger RNA levels. Nature 1990;343: 536 - 40. [PubMed][CrossRef]

6. Liu X, Zwiebel LJ, Hinton D et al. The period gene encodes a predominantly nuclear protein in adult Drosophila. J Neurosci 1992; 12: 2735 - 44. [PubMed]

7. Vosshall LB, Price JL, Sehgal A et al. Block in nuclear localization of period protein by a second clock mutation, timeless. Science 1994; 263: 1606 - 9. [PubMed][CrossRef]

8. Price JL, Blau J, Rothenfluh A et al. double-time is a novel Drosophila clock gene that regulates PERIOD protein accumulation. Cell 1998; 94: 83 - 95. [PubMed][CrossRef]

9. Young MW. Life's 24-hour clock: molecular control of circadian rhythms in animal cells. Trends Biochem Sci 200o; 25: 601 - 6. [PubMed][CrossRef]

10. Ballesta A, Innominato PF, Dallmann R et al. Systems Chronotherapeutics. Pharmacol Rev 2017; 69: 161 - 99. [PubMed][CrossRef]

11. Menet JS, Rosbash M. When brain clocks lose track of time: cause or consequence of neuropsychiatric disorders. Curr Opin Neurobiol 2011; 21: 849 - 57. [PubMed][CrossRef] 